\title{
Historic Preservation and its Cultured Despisers: Reflections on the Contemporary Role of Preservation Law in Urban Development
}

\author{
J. Peter Byrne \\ Georgetown University Law Center, byrne@law.georgetown.edu
}

Georgetown Public Law and Legal Theory Research Paper No. 12-021

Georgetown Business, Economics and Regulatory Law Research Paper No. 12-007

This paper can be downloaded free of charge from:

https://scholarship.law.georgetown.edu/facpub/784

http://ssrn.com/abstract=2013278

19 Geo. Mason L. Rev. (forthcoming)

This open-access article is brought to you by the Georgetown Law Library. Posted with permission of the author. Follow this and additional works at: https://scholarship.law.georgetown.edu/facpub 


\title{
HISTORIC PRESERVATION AND ITS CULTURED DESPISERS: REFLECTIONS ON THE CONTEMPORARY ROLE OF PRESERVATION LAW IN URBAN DEVELOPMENT
}

\author{
J. Peter Byrne*
}

\section{INTRODUCTION}

Historic preservation has come of age. It plays a major role in how property development occurs in communities of all sorts across the nation. ${ }^{1}$ The National Historic Preservation $\mathrm{Act}^{2}$ and other federal preservation statutes ${ }^{3}$ exert a pervasive influence on how the federal government manages its own projects, as well as on how federal agencies fund and permit projects by private entities and state and local governments. ${ }^{4}$ Localities market themselves to developers and visitors by touting their historic resources. ${ }^{5}$ But most importantly, local historic preservation laws regulate the demolition and alteration of numerous designated historic buildings and sites within many of the most dynamic urban real estate markets, including New York City; Washington, D.C.; Boston; Philadelphia; and San Francisco. ${ }^{6}$ One can no longer analyze contemporary urban development and redevelopment with regard to historic preservation.

Such prominence understandably generates criticism. The past years have seen widely noticed critiques of historic preservation by "one of our leading urban economists," ${ }^{7}$ Edward Glaeser, and by star architect Rem Koolhaas. Glaeser, an academic economist specializing in

\footnotetext{
* J. Peter Byrne is a Professor of Law at the Georgetown University Law Center. Thanks for helpful research goes to Deborah Newburg.

The title of this article alludes to Friedrich Schleirmacher, On RELIGION: SPEECHES TO ITS Cultured DeSPISERS (1799; tr., Richard Crouter, 1988). Although historic preservation lacks the profundity of religion, it similarly seeks to nurture and communicate meaning broadly. It also is likely to be slighted by rationalist and heroic materialist critics.

${ }^{1}$ Another indication of maturity is the publication of the first casebook, SARA C. BRONIN \& J. PETER BYRne, Historic PRESERVATION LAW (forthcoming 2012).

216 U.S.C. $\S 470$ (2006).

${ }^{3}$ See, e.g., Archaeological Resources Protection Act of 1979, 16 U.S.C. §§ 470aa-470mm (2006); Coastal Zone Management Act of 1972, 16 U.S.C. §§ 1451-1466 (2006); National Environmental Policy Act of 1969, 42 U.S.C. §§ 4321-4370f (2006).

${ }^{4}$ The pervasive nature of federal preservation law can be seen in the large number of "undertakings" subject to historic preservation review under Section 106 of the National Historic Preservation Act. 16 U.S.C. § 470f (2006). The National Park Service reports for 2010 that: "State Historic Preservation Offices reviewed 242,000 Federal undertakings, compared to 106,900 in 2009, providing 112,000 National Register eligibility opinions. Tribal Historic Preservation Offices reviewed 34,600 undertakings and made 7,150 eligibility opinions.” NAT’L PARK SERV., HISTORIC PRESERVATION FUnd ANNUAL REPORT 2010 (2011).

${ }^{5}$ The District of Columbia Comprehensive Plan, for example, recognizes the centrality of historic preservation to development and economic growth.

Historic preservation is also fundamental to the growth and development of District neighborhoods. Recent building permit and development activity in the city confirms that historic preservation is a proven catalyst for neighborhood investment and stabilization. The financial impact of preservation on the city is also well documented. Preservation has increased real estate values, strengthened the city's tourism industry, and revitalized neighborhood shopping districts like Barracks Row and U Street.

D.C. OfFice of PlanNing, THE COMPREHENSIVE Plan For the NATIONAL CAPITAL: District Elements 10-27 (2006).

${ }^{6}$ S.F., CAL., PlanNing CODE art. 10, § 1006 (2007); D.C. CODE § 6-1104 (2001); BOS., MASS., CODE OF ORDINANCES § 7-3.4

(2011); N.YC., N.Y., RCNY tit. 63, § 6-04 (2008); PHILA., PA., CODE AND CHARTER tit. 14, § 14-2007(7)(a) (2009).

${ }^{7}$ David J. Reiss, Book Review: Edward L. Glaeser, Triumph of the City: How Our Greatest Invention Makes Us Richer, Smarter, Greener, Healthier, and Happier, ENV’T \& PLAN. A (forthcoming 2012) (manuscript at 1) (book review), available at http:/ssrn.com/abstract=1968588.
} 
urban development, admits that preservation has value. ${ }^{8}$ But he argues in his invigorating book, Triumph of the City, and in a contemporaneous article, Preservation Follies, that historic preservation restricts too much development, raises prices, and undermines the vitality of the cities. $^{9}$ Koolhaas is a Pritzker Prize-winning architect and oracular theorist of the relation between architecture and culture. In his New York exhibit, Cronocaos, he argued that preservation lacks an organizing theory, imposes inauthentic consumer-friendly glosses on older structures, and inhibits architectural creativity. ${ }^{10}$ Although these critiques are as different as the cultural spaces inhabited by their authors (although both are professors at Harvard), both seemed to strike nerves, suggesting an underlying unease about how large a role preservation has come to play in urban development. This Article assesses these critiques as part of an ongoing effort to make sense of historic preservation law.

The Article proceeds as follows: First, it presents Glaeser's critique in detail, placing it within the context of his larger argument about what makes cities attractive and dynamic. Grappling with the strengths and weaknesses of Glaeser's critique leads to a discussion of how preservation regulation actually works and clarification of some of the benefits it confers. Second, this Article will attempt to specify Koolhaas's critique, connecting it to similar complaints about preservation by more linear thinkers. Weighing objections to the coherence or authenticity of preservation leads to further discussion of the role that preservation plays in the larger culture. The Article concludes with a call for future research.

\section{PRESERVATION FOLLIES AND ACCOMPLISHMENTS}

Edward Glaeser's Triumph of the City presents a full-hearted celebration of modern cities as engines of wealth creation, innovation, creativity, and environmental sustainability. ${ }^{11}$ Although written for a general readership, it draws on Glaeser's academic work as an urban economist. He argues that dense agglomerations of creative people lead to breakthrough innovations in business and culture and that such advantages are even more central to contemporary economies based on information and technological innovation. ${ }^{12}$ Glaeser believes that high-rise density allows more talented people of diverse levels of wealth to live in desirable cities. ${ }^{13}$ He states that "[c]ities thrive when they have many firms and skilled citizens." ${ }^{14} \mathrm{He}$ repeatedly expresses concern that land use regulations restrict new construction, raise housing prices, and exclude lower income people. ${ }^{15}$ Glaeser notes that "[t]he cost of restricting

${ }^{8}$ See EdWARd GlaESER, Triumph OF THE City: How Our GREATEST INVENTION MAKES Us Richer, SMARTER, GREENER, HEALTHIER, AND HAPPIER 12 (2011).

${ }^{9}$ See id. at 262-63; Edward L. Glaeser, Preservation Follies: Excessive Landmarking Threatens to Make Manhattan a Refuge for the Rich, CITY J., Spring 2010, at 62, 62.

${ }^{10}$ See Nicolai Ouroussoff, An Architect's Fear that Preservation Distorts, N.Y. TimEs, May 24, 2011, at C1, C1.

${ }^{11}$ See Reiss, supra note Error! Bookmark not defined. (manuscript at 2); Diana Silver, Up, Up, Up, N.Y. TIMEs, Feb. 13, 2011, at 21, 21.

${ }^{12}$ Glaeser emphasizes the advantages from information exchange among many small entrepreneurs, contrasting the creation of the automobile industry in Detroit, where many small inventors pushed forward car and production technologies, and the decline of the same industry dominated by a few very large institutions. GLAESER, supra note 8, at 47-49. He also, without any sense of irony, compares artistic creations in Renaissance Florence with hedge fund innovation in New York during the past decade. Id. at 56-57. For a legal academic evaluation of Glaeser’s positive analysis see - Cite Rodriguez and Schleicher paper from panel?

${ }^{13}$ GLAESER, supra note 8,at 6-7.

${ }^{14}$ GLAESER, supra note 8, at 8.

${ }^{15}$ GLAESER, supra note 8, at 191-93. 
development is that protected areas become more expensive and more exclusive. . . The basic economics of housing process are pretty simple-supply and demand." ${ }^{16}$ Although he waxes rhapsodically about New York, his ideal for land use regulation seems to be Houston, Texas. ${ }^{17}$

Glaeser's basic complaint about historic preservation is that protection of too many buildings, especially in historic districts, gives too much power to neighbors to prevent new high rise development, construction of which could preserve affordable housing costs. ${ }^{18}$ Although he accepts the "worthy cause of protecting the most beautiful reminders of our past," ${ }^{19}$ he views modern local preservation laws primarily as legal tools by which the wealthy and powerful exclude high rise developments from their cozy historic districts. For instance, he states that "[t]he well-heeled denizens of historic districts convincing the Landmarks Preservation Commission to stop taller structures have become the urban equivalent of those restrictive suburbanites who want to mandate five-acre lot sizes in order to keep out the riffraff." ${ }^{20}$ Focusing primarily on New York City, he laments the growth in the number of protected buildings ${ }^{21} \mathrm{He}$ also argues that such growth has systematic effects on prices, so that housing prices have grown more rapidly in historic districts and may be responsible for average city-wide increases. ${ }^{22} \mathrm{He}$ states that "census data show that there has indeed been less new housing built in historic districts, even though they are some of the most attractive areas in New York." ${ }^{23}$

Glaeser's critique of preservation law gains detail in his consideration of specific cases. As an example of his concern, he discusses a dispute about building a twenty-two-story glass tower over a four-story 1949 Art Moderne façade at 980 Madison Avenue. ${ }^{24}$ The Landmarks Preservation Commission rejected the initial design, even though renowned architect Norman Foster designed it, because its height was out of scale with its surroundings and with the original building. ${ }^{25}$ In Glaeser's account, “[w]ell connected neighbors didn't like the idea of more height." ${ }^{26}$ He makes the counterintuitive suggestion that when the Commission agrees to demolish a building, it "should demand that its replacement be as tall as possible." ${ }^{27}$ That is because "building up in one area reduces the pressure to take down other older buildings." ${ }^{28}$ The site was within the Upper East Side Historic District, which Glaeser more generally criticizes as "a large swath of Manhattan ... [without] any architectural unity." 29

In general, Glaeser believes that enacting the Landmark Preservation Ordinance was a sort of reflexive public response to the demolition of Penn Station in 1962 by the Pennsylvania Railroad. ${ }^{30} \mathrm{He}$ also believes that, "like entropy, the reach of governmental agencies often

\footnotetext{
${ }^{16}$ GLAESER, supra note 8 , at 150 .

${ }^{17}$ GLAESER, supra note 8 , at $183-88$.

${ }^{18}$ GLAESER, supra note 8, at 260-64.

${ }^{19}$ GLAESER, supra note 8, at 260-61.

${ }^{20}$ GLAESER, supra note 8, at 150 .

${ }^{21}$ GLAESER, supra note 8, at 161-63; Glaeser, supra note 9, at 62.

${ }^{22}$ GLAESER, supra note 8, at 150-51; Glaeser, supra note 9, at 66.

${ }^{23}$ GLAESER, supra note 9, at 65.

${ }^{24}$ GLAESER, supra note 8, at 149; Glaeser, supra note 9, at 65.

${ }^{25}$ GLAESER, supra note 8, at 149; Glaeser, supra note 9, at 65.

${ }^{26}$ GLAESER, supra note 8, at 149; Glaeser, supra note 9, at 65.

${ }^{27}$ GLAESER, supra note 8, at 150.

${ }^{28}$ GLAESER, supra note 8, at 150.

${ }^{29}$ GLAESER, supra note 9, at 64.

${ }^{30}$ GLAESER, supra note 8, at 148-49. The agitation for a historic preservation ordinance in New York City substantially preceded the destruction of Penn Station. See Anthony C. Wood, Preserving NEW YorK: Winning the Right to Protect a City's
} 
increases over time, so that a mild, almost symbolic, group can come to hold sway over vast swaths of a city." ${ }^{31}$ He describes NIMBYism, i.e., neighbor opposition to locally undesirable land uses "in my backyard," as a "[c]urse." ${ }^{2}$ He makes a very broad statement: "The interests of people who oppose change are certainly comprehensible, but their interests usually don't match the public interest." ${ }^{33} \mathrm{He}$ attributes such opposition to psychological biases against change. ${ }^{34}$ Moreover, he makes the legal observation that opponents of a project "want to control somebody else's property." 35 Thus, "stopping growth isn't so much maintaining the status quo as it is taking someone else's rights and reducing the value of someone else's property." 36 The context makes it clear that he includes preservationists within these accusations.

Glaeser raises some valid concerns. Everything else being equal, restricting supply does increase price. Affordable housing is a serious problem in New York and other cities with strong preservation laws. Also, neighbors plainly do use preservation laws to secure benefits other than heritage protection, such as views and light. ${ }^{37}$ Most local preservation laws extend protection to every "contributing" building within an historic district. ${ }^{38}$ People who are indifferent to architectural history and oppose a new development for collateral reasons, such as increased traffic, can argue that the new development is inappropriate in scale or design for the district. The problem here primarily is the half-hearted, often improvisational, land use planning law that prevails in American cities, which encourages opponents of development to employ ill-suited available tools to protect their interests. ${ }^{39}$ The Article takes up these problems below.

Glaeser's assault, however, greatly mischaracterizes preservation law both in its effects and in its role in urban life. He surely exaggerates the effect of preservation laws on urban house prices. He makes much of the fact that $16 \%$ of the land in Manhattan, south of $96^{\text {th }}$ Street, is under the jurisdiction of the Landmarks Preservation Commission. ${ }^{40}$ But, of course, that means that $84 \%$ is not. Moreover, 29,000 properties in the entire city have been designated, mostly in historic districts, but that is less than $0.3 \%$ of the properties on the City's tax survey. ${ }^{41}$ Even if

LANDMARKs 6-10 (2008). Proponents in favor of establishing historic districts in Brooklyn Heights and Greenwich Village also played crucial roles. See id. at 167-227. The roots of historic preservation in New York can be traced back to the nineteenth century. See Randall Mason, The Once and Future New York: Historic Preservation and the Modern City, at xxiii (2009).

${ }^{31}$ GLAESER, supra note 8, at 149.

${ }^{32}$ GLAESER, supra note 8, at 260.

${ }^{33}$ GLAESER, supra note 8, at 261-62.

${ }^{34}$ GLAESER, supra note 8, at 262.

${ }^{35}$ GLAESER, supra note 8, at 262.

${ }^{36}$ GLAESER, supra note 8, at 262,

${ }^{37}$ Cf. Carol M. Rose, Preservation and Community: New Directions in the Law of Historic Preservation, 33 StAN. L. REV. 473, 47576 (1981) (discussing various ways that people use historic preservation laws to achieve personal or community goals).

${ }^{38}$ See AleXAnder Garvin, American CitY: What WorKs, What DOESN’T 479 (2d ed. 2002); see also Athens-Clarke Cnty., Ga., Code of Ordinances: Sec. 8-5-3: Designation of Historic Districts and Landmarks, MuNICODE,

http://library.municode.com/index.aspx?clientId=12400\&stateId=10\&stateName=Georgia (last visited Jan. 27, 2012) (use table of contents to navigate to Section 8-5-3 within Part III, Title 8); Portland, Or. Bureau of Planning and Sustainability, Historic Resource Rules and Benefits, PORTLANDONLINE, http://www.portlandonline.com/bps/index.cfm?a=133692\&c=39750 (last visited Jan. 13, 2012).

${ }^{39}$ See GARVIN, supra note 38, at 464-65.

${ }^{40}$ See GLAESER, supra note 9, at 62, 64.

${ }^{41}$ See City of N.Y., Dep’t of Fin. \& Office of TAX Policy, ANNual RePort of the NYC Property Tax Fiscal Year 2011, at $i$ (2011) (showing the number of citywide properties as 1,069,304); New York City Landmarks Preservation Commission, THE N.Y. PREs. ARChIVE PRoJect, http://www.nypap.org/content/new-york-city-landmarks-preservation-commission-0 (last visited Jan. 13, 2011). 
these districts were frozen in amber, developers would have nearly the entire city in which to build without preservation restraint. Moreover, given the attractiveness of historic districts, one would expect substantial development just beyond their boundaries, zoning permitting, and, anecdotally, this seems common. Historic districts spread economic demand to new areas, strengthening the city overall and providing significant windfalls to property owners in the right locations. Washington, D.C. probably has the highest percentage of total land covered by historic preservation protections of any major city, at nearly $20 \%$, but has experienced rapid population gains in recent years and has issued permits for substantially more new housing. ${ }^{42}$

Glaeser has a superficial knowledge of historic preservation law. Contrary to his belief, preservation ordinances do not prohibit new development. Even strong ordinances, like those in New York, permit alterations and new construction when they are "appropriate." ${ }^{43}$ In considering a proposal to construct, alter, or demolish any structure located in a historic district, the Commission must assess the effect of the proposed work on existing architectural features, the relationship between the proposed work, and the exterior features of neighboring improvements. Specifically, the Commission considers the "factors of aesthetic, historical, and architectural values" and the architectural style, design, texture, materials, and colors of the proposed work. ${ }^{44}$ The Commission does not have jurisdiction to regulate the height of buildings, but it can do so when the height of additions impair values of the subjects or surrounding properties. ${ }^{45}$ This is evident in the landmark case, Penn Central Transportation Co. v. New York City, ${ }^{46}$ where the Commission had rejected the fifty-story modernist tower addition on top of the Grand Central Station because it impaired the overall appearance of the station. ${ }^{47}$ The Court noted that the owner failed to show that the Commission would not grant a permit for a smaller, more compatible addition. ${ }^{48}$

In practice, preservation commissions often permit large additions to protected buildings or tall, new buildings in historic districts. For instance, New York's Landmarks Preservation Commission approved a thirty-six-floor tower (also designed by Norman Foster) above the sixstory Hearst Building. ${ }^{49}$ In addition, despite the strong opposition by neighborhood and preservation groups, the Philadelphia Historical Commission approved the partial demolition of a historic three-story house, and the construction of a sixteen-story condominium as an addition; the Pennsylvania Commonwealth Court recently upheld the decision. ${ }^{50}$ The Historic Preservation Review Board in Washington, D.C. has permitted many tall buildings set behind or on top of historic row houses in commercial areas. ${ }^{51}$ Some of these are beautiful and some are hideous, but

\footnotetext{
${ }^{42}$ See Bureau of Land Management, Dep't OF THe Interior, Public Land Statistics, at Table 1-3 (1998) (stating that the District of Columbia contains 39,040 acres of land); Carol Morello \& Timothy Wilson, Number of District Residents Skyrockets, WASH. PosT, Dec. 22, 2011, at A1, A6 ("There are signs that the city is poised to keep getting bigger. In the first nine months of this year, the city approved building permits for 3,000 new housing units . ..."); Larry Van Dyne, Tear it Down! Save it!, WASHINGTONIAN, Mar. 2009, at 48, 56. Cite stats from Maloney e-mail.

${ }^{43}$ N.Y.C., N.Y., ADMINISTRATIVE CODE tit. 25, § 25-307(a) (2000).

${ }^{44} I d . \S 25-307(\mathrm{~b})(2)$

${ }^{45}$ Id.; § 23-307(b)(3).

46438 U.S. 104 (1978).

${ }^{47} \mathrm{Id}$. at $116-17$.

${ }^{48}$ Id. at 137.

${ }^{49}$ See David W. Dunlap, Landmarks Group Approves Bold Plan for Hearst Tower, N.Y. TimES, Nov. 28, 2001, at D1, D1; see also Nicolai Ouroussoff, Upward Mobility, At Last, N.Y. TIMEs, June 9, 2006, at E29, E29, E37.

${ }^{50}$ Turchi v. Phila. Bd. of License \& Inspection Review, 20 A.3d 586, 596 (Pa. Commw. Ct. 2011).

${ }^{51}$ Van Dyne, supra note 42, at 84-85.
} 
they have allowed the creation of higher densities within historic districts. New York has resisted the practice of what is sometimes derided as "façadectomy," 52 but has allowed increased density for new buildings in historic districts. In the case dealing with 980 Madison Avenue, discussed by Glaeser, in fact, the Commission eventually approved a lower but broader design that gave the developer nearly all the increased density initially sought. ${ }^{53}$

In addition to the flexibility evinced in the application of a standard such as appropriateness or compatibility, some preservation ordinances have "safety valve" provisions. ${ }^{54}$ These allow officials to approve projects that do not meet applicable standards if they offer unusually important public benefits. The best known version is the "special merit" provision of Washington, D.C. ${ }^{55}$ A project of "special merit" is "a plan or building having significant benefits to the District of Columbia or to the community by virtue of exemplary architecture, special features of land planning, or social or other benefits having a high priority for community services." ${ }^{56}$ A quasi-judicial administrative official, known as the "Mayor's Agent," can issue a permit for demolition or alteration otherwise denied by the Historic Preservation Review Board after a contested hearing. ${ }^{57}$ Permits issued pursuant to this provision have largely been confined to projects with exceptional public benefits, such as a municipal convention center and a museum addition designed by architect Frank Gehry. ${ }^{58}$

Other jurisdictions have devices to supersede the normal effect of their preservation ordinances with varying degrees of sophistication. Philadelphia's law provides, for example, that

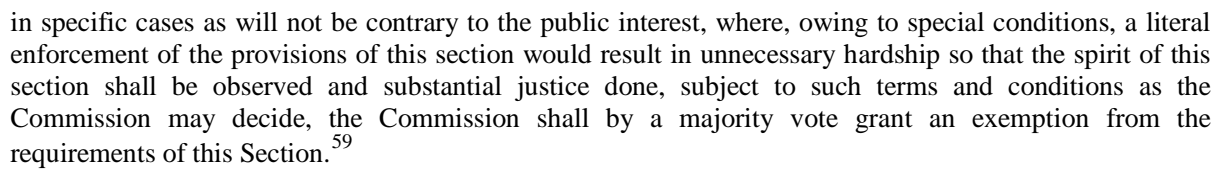
enforcement of the provisions of this section would result in unnecessary hardship so that the spirit of this section shall be observed and substantial justice done, subject to such terms and conditions as the Commission may decide, the Commission shall by a majority vote grant an exemption from the requirements of this Section. ${ }^{59}$

New York City lacks any safety valve provision for granting permits, which has put substantial pressure on its designation decisions. The Chair of the Landmarks Preservation Commission has asserted a nearly absolute discretion not to schedule designation hearings for controversial

\footnotetext{
${ }^{52}$ See Nicolai Ouroussoff, Redesigning a Building to Preserve Peace in the Neighborhood, N.Y. TIMES, May 14, 2008, at E5, E5 (describing residents' objections to a project which would preserve two brownstone facades but would also expand construction behind the buildings); Façadectomy, WoRDSPy (last visited Jan. 27, 2012), http://wordspy.com/words/facadectomy.asp (defining "façadectomy").

${ }^{53}$ See Ouroussoff, supra note 52, at E5; Jennifer B. Lee, Panel Approves Smaller Expansion of Upper East Side Building, N.Y. TiMEs (Oct. 14, 2009, 12:39 PM), http://cityroom.blogs.nytimes.com/2009/10/14/panel-approves-smallerexpansion-of-upper-east-side-building/?scp=3\&sq=980\%20madison\%20avenue\%20preservation\&st=cse. ${ }^{54}$ D.C. CODE § 6-1102(11) (2001).

${ }^{55} \mathrm{Id}$.

${ }^{56} I d$.

${ }^{57}$ Id.; §§ 6-1102(8), 6-1107(f).

${ }^{58}$ See Comm. of 100 on the Fed. City v. D.C. Dep’t of Consumer \& Regulatory Affairs, 571 A.2d 195, 204 (D.C. 1990) (overturning special merit findings when benefits are common to the new development). The decisions of the Mayor's Agent are collected on the Georgetown Law Library's website, http://www.ll.georgetown.edu/histpres/decisions.cfm. The author of this Article recently has been appointed as the current Mayor's Agent.

${ }^{59}$ PHILA., PA., CODE AND CHARTER tit. 14, § 14-2007(4)(k)(.7) (2009); see also Phila. Historical Comm'n, Rules \& Regulations, PHILA.GOV, at 36, 58 http://www.phila.gov/historical/pdf/Rules_Regs_2112010.pdf (last visited Jan. 27, 2012) (containing sections 6.9(a)(7) and 11(1), which use almost identical language as the Philadelphia Code and Charter).
} 
properties, which, so far, has been upheld by the courts. ${ }^{60}$ Yet, every historic preservation ordinance regulating private property needs some safety valve provision to recognize that preservation values can be outweighed in an exceptional case by another strong public interest; the challenge is to prevent it from becoming a loophole that undermines preservation.

Glaeser's account emphasizes a preservation commission's supposed susceptibility to protect the interest of the rich and famous. There is no doubt that such persons' ability to hire lawyers and experts, as well as their ability to command media coverage, make them formidable parties. But developers who are repeat players before commissions must be just as resourceful and even more motivated by self-interest. In any event, Glaeser ignores the fact that commission members are essentially pro bono volunteers, rather than career politicians seeking campaign contributions. ${ }^{61}$ Nearly every preservation ordinance requires that members of a commission have some relevant expertise, such as history, architecture or real estate, or a demonstrated interest in preservation. ${ }^{62}$ Most commissioners can be expected to favor preservation rather than the incidental interests of well-healed neighbors. ${ }^{63}$

Glaeser's equation of urban historic districts with suburban exclusionary zoning misleads more than it clarifies. His claim is that restricting a historic neighborhood to relatively low-density, older buildings drives up prices and excludes lower income residents. ${ }^{64}$ In suburban exclusionary zoning, smaller jurisdictions zone substantially all of their land for large singlefamily homes on large lots, in order to exclude low income residents and keep educational and welfare expenditures and tax rates low. ${ }^{65}$ Glaeser must be right that some homeowners in both contexts seek to distance themselves from low income people for psychic or economic benefit. But the difference between the two scenarios is significant. Most historic districts contain some low cost housing, because neglect by the market allowed such neighborhoods to survive intact architecturally until preservation laws were enacted and designation were accomplished. ${ }^{66}$ Designation preserves that affordable housing. Gentrification, if it occurs, takes time; community members often employ government programs to keep some local housing affordable despite rising prices. ${ }^{67}$ Empirical research shows that low income residents move from gentrifying

\footnotetext{
${ }^{60}$ See Citizens Emergency Comm. to Pres. Pres. v. Tierney, 896 N.Y.S.2d 41, 43 (App. Div. 2010). The Chair’s refusal to bring certain properties to a hearing on designation has been extremely controversial. See, e.g., Robin Pogrebin, Fighting on to Preserve Morningside Heights, N.Y. TIMES, Mar. 2, 2009, at C1, C5.

${ }^{61}$ See N.Y.C., N.Y., N.Y.C. CHARTER § 3020 (2010) ("The members of the commission other than the chair, shall serve without compensation, but shall be reimbursed for expenses necessarily incurred in the performance of their duties.”).

${ }^{62}$ See, e.g., id.; see also Phila. Historical Comm'n, supra note 59, at 12-13 (containing sections 3.4(a) and (b)).

${ }^{63}$ See J. Peter Byrne, Regulatory Takings Challenges to Historic Preservation Laws After Penn Central, 15 FORDHAM ENVTL. L. REV. 313, 316 (2004) (noting the extreme infrequency of successful challenges to historic preservation designation); Rose, supra note 37, at 531-33 (discussing the conflicting motives and official obstacles faced by wealthy residents in disputes over preservation designation); Todd Schneider, Comment, From Monuments to Urban Renewal: How Different Philosophies of Historical Preservation Impact the Poor, 8 GEO. J. ON POVERTY L. \& POL'Y 257, 265 (2001) (discussing the frequent appointment of commissioners likely to favor preservation and the susceptibility of preservation commissions to outside interests).

${ }^{64}$ GLAESER, supra note 9, at 66.

${ }^{65}$ See S. Burlington Cnty. N.A.A.C.P. v. Twp. of Mount Laurel, 336 A.2d 713, 719-20 (N.J. 1975); Robert P. Inman \& Daniel L. Rubinfeld, The Judicial Pursuit of Local Fiscal Equity, 92 HARV. L. REV. 1662, 1685-89 (1979) (describing economic incentives for exclusionary zoning).

${ }^{66}$ Donovan D. Rypkema, Historic Preservation and Affordable Housing: The Missed Connection, F.J., Spring 2003, at 4, 11 (noting that about 60 percent of buildings in historic districts are located in census tracts where the poverty level is above 20 percent).

${ }^{67}$ For example, the notorious slum apartment complex involved in Javins v. First National Housing Corp., 428 F.2d 1071 (D.C. Cir. 1970), which established the implied warranty of habitability in rental housing, was listed on the National Register in 2001 and subsequently received historic preservation tax credits, which enabled a successful renovation of the complex as mixed income
} 
neighborhoods at lower rates than from non-gentrifying neighborhoods. ${ }^{68}$ Research also suggests that many new residents attracted to historic districts want to honor and keep in place traditional residents. ${ }^{69}$ Even more fundamentally, unlike exclusionary suburbs, historic districts are small parts of large, diverse, local government jurisdictions. Lower income residents vote in the same local jurisdiction as their higher income counterparts; indeed, low income citizens arguably have their strongest political voices in such cities. Moreover, higher income residents have weaker incentives to exclude lower income individuals from urban historic districts because doing so will have no effect on tax burdens or educational or welfare expenditures. ${ }^{70}$

Glaeser argues that preservation law allows neighbors to reduce the value of an owner's property and control or "take" his property. ${ }^{71} \mathrm{He}$ makes no reference to Penn Central, which made it clear that preservation controls on private property ordinarily do not take away an owner's property rights, even if they substantially reduce its economic value. ${ }^{72}$ Professor Gregory Alexander has offered a persuasive explanation of the constitutional principle:

Private ownership of those aspects of a society's infrastructure upon which the civic culture depends comes with special obligations. ... The development of Grand Central Terminal contemplated in Penn Central would have inflicted on the community of New York a significant loss of cultural meaning and identity. No compensation should be constitutionally required to prevent a private owner from inflicting such a loss in the first place, a loss that is fundamentally at odds with the obligations of the owner of that property. ${ }^{73}$

The cultural heritage conveyed by a community's historic buildings is a public good, the value of which is not fully internalized in private property rights. Because private owners cannot fully capture the value of historic preservation, public ownership or regulations are necessary to protect the public's interests in their heritage. Regulation may be done well or poorly, but regulation must exist.

Glaeser's primary complaint is against historic districts, which he claims "include thousands of utterly undistinguished structures." "Given that focus, his claims that preservation regulations take property rights are even less persuasive. In his forceful dissent in Penn Central, Justice Rehnquist fully accepted that historic district ordinances do not normally take property from any owner because each enjoyed an "average reciprocity of advantage." ${ }^{2}$ In other words, each owner in the district was both burdened by the restrictions on his own use and benefitted by

condominiums and rentals in a gentrifying neighborhood. BRONIN \& BYRNE, supra note 1 (manuscript at 79-80); Richard H. Chused, Saunders (a.k.a. Javins) v. First National Realty Corporation, 11 GEO. J. ON POVERTY L. \& POL’Y 191, 194-95 (2004).

${ }^{68}$ See Lance Freeman \& Frank Braconi, Gentrification and Displacement: New York City in the 1990s, 70 J. AM. PLAN. Ass'N 39, 45 (2004); Jacob L. Vigdor, Does Gentrification Harm the Poor?, BrooKIngs-WharTON PAPERS ON URB. AfF. 133, 149 (2002).

${ }^{69}$ See Maureen Kennedy \& Paul Leonard, Dealing with Neighborhood Change: A Primer on Gentrification AND POLICY CHOICES 39 (2001), available at

http://www.brookings.edu/ /media/Files/rc/reports/2001/04metropolitanpolicy_maureen\%20kennedy\%20and\%20paul\%20leonard/g entrification.pdf; Rypkema, supra note 66, at 11 (indicating that over 14 percent of new residents chose to live in historic neighborhoods because of the neighborhoods' looks and design). JAPONICA BROWN-SARACINO, A NEIGHBORHOOD THAT NEVER CHANGES: GENTRIFICATION, SOCIAL PRESERVATION, AND THE SEARCH FOR AUTHENTICITY (2010).

${ }^{70}$ BRONIN \& BYRNE, supra note 1 (manuscript at 79).

${ }^{71}$ GLAESER, supra note 8, at 262.

${ }^{72}$ Penn Central Transp. Co. v. City of N.Y., 438 U.S. 104, 124-25 (1978).

${ }^{73}$ Gregory S. Alexander, The Social Obligation Norm in American Property Law, 94 CoRNELL. L. ReV. 745, 795-96 (2009).

${ }^{74}$ GLAESER, supra note 9, at 62.

${ }^{75}$ Penn Central, 438 U.S. at 140 (Rehnquist, J., dissenting) (quoting Pa. Coal Co. v. Mahon, 260 U.S. 393, 415 (1922)). 
the restrictions on his neighbor's uses. ${ }^{76}$ Rehnquist's primary concern was that individual landmarks did not enjoy such reciprocity. ${ }^{77}$ The Court in Penn Central held that protection, even of an isolated landmark as part of a comprehensive landmark protection plan, offers adequate benefits to the landmark owner so that the Constitution does not require the government to provide compensation. ${ }^{78}$ Indeed, preservation laws nationwide have resulted in less than a handful of adjudicated regulatory takings ever. ${ }^{79}$

While an economist's ignorance of the law may be excusable, the superficiality of Glaeser's analysis of the economics of preservation is startling. He claims that neighbors enforcing preservation laws are "taking someone else's rights and reducing the value of someone else's property." ${ }^{80}$ But preservation generally does not reduce property values. Glaeser himself reports that his studies show that property in New York City's historic districts rose in value more than comparable property outside them. ${ }^{81}$ This is consistent with the bulk of empirical research, which finds that historic district preservation increases or holds constant property values. ${ }^{82} \mathrm{He}$ argues that this rise is caused by restricting the supply of new housing through preservation. ${ }^{83}$ But nowhere does he consider that preservation law increases demand for housing within historic districts because purchasers value the unique buildings and streetscapes protected from demolition and incompatible alteration. ${ }^{84}$ Urban land values are largely determined by what structures and land uses are near them ("location, location, location"), ${ }^{85}$ and they comprise a substantial percentage of urban real estate values. ${ }^{86}$ Moreover, historic districts also encourage landowners to invest further in their own properties because they can have confidence that their neighbors will not erect inappropriate structures that will undermine and reduce the value of their own property. ${ }^{87}$

An individual owner of property in a historic district can reap a windfall if he is exempted from restrictions while surrounding buildings remain bound. He could build large buildings, which would benefit from the attractive context of older smaller buildings, without contributing to the preservation of that context. But his lucrative, inappropriate development would diminish the attractions of the ensemble, reducing the value of his neighbor's properties. While one exceptional tall building may impose only marginal harm on the ensemble, repeated exceptions eventually would destroy whatever value the historic district itself conferred on individual properties. Glaeser himself seems oblivious to what makes historic districts desirable, arguing that any time a preservation commission permits demolition of a structure within a

${ }^{76}$ Id. at $139-40$.

${ }^{77} \mathrm{Id}$. at 140.

${ }^{78}$ Id. at 136-38. Hanoch Dagan has justified the court's balance of private burdens and public benefits in Penn Central in the context

of his emphasis on "long-term reciprocity of advantage" as key to the regulatory takings doctrine. Hanoch Dagan, Takings and

Distributive Justice, 85 VA. L. REV. 741, 797-99 (1999).

${ }^{79}$ Byrne, supra note 63 , at 316.

${ }^{80}$ GLAESER, supra note 8, at 226.

${ }^{81}$ GLAESER, supra note 9, 66.

${ }^{82}$ See, e.g., Donovan D. Rypkema, The (Economic) Value of National Register Listing, Cultural Resource MgMT., 2002, at 6, 6.

${ }^{83}$ GLAESER, supra note 9, 66.

${ }^{84}$ See generally GLAESER, supra note 8; Glaeser, supra note 9.

${ }^{85}$ See Andrew Haughwout, James Orr \& David Bedoll, The Price of Land in the New York Metropolitan Area, CuRRENT IssuES ECON. \& FIN., 2008, at 1, 4.

${ }^{86}$ See Morris A. Davis \& Michael G. Palumbo, The Price of Residential Land in Large U.S. Cities, 63 J. URB. ECON. 352, 362 (2008) (finding that, in 2004, land constituted 51 percent of the value of residential property in the United States).

${ }^{87}$ Cite? 
historic district, it "should demand that its replacement be as tall as possible." ${ }^{88}$ His point is that the tall building will soak up some demand for new housing and diminish pressure to demolish other buildings. ${ }^{89}$ But his economist's focus on increasing supply ignores the reality that the demand for living in the historic district is driven by the attractiveness of the ensemble of buildings and other infrastructure that make the district historically significant.

Glaeser expresses no curiosity about why people seek to live in or visit historic districts; he seems to view them simply as devices to prohibit virtuous new development. His explanation of the growth of preservation in New York after the enactment of the Landmarks Preservation Ordinance loosely invokes "entropy" and the platitude that bureaucracies seek to extend their power. ${ }^{90}$ While Glaeser is, of course, correct that smaller buildings have some appeal because of the more human scale and access to some small gardens, ${ }^{91}$ many other factors also are at play. The aesthetic qualities of domestic, pre-1914 architecture beguile the modern sensibility. The natural building materials, such as a stone, wood, and brick, as well as the proportions and symmetry of many prevalent styles (such as federal or Italianate), convey traditional virtues. Other styles may convey other historical themes, such as Victorian domesticity, ethnic solidarity, or craft-scale industry. Unlike modern subdivisions or housing projects, traditional urban neighborhoods contain genuine varieties of style, shape, and age within unifying contexts of period and local history. Thus, visually, the most successful historic neighborhoods contain a pleasing balance between variety and unity, neither boring nor chaotic. Moreover, row houses and other traditional homes are oriented toward pedestrian space, with front doors and windows opening onto sidewalks. All this amounts to the ideals of new urbanism, which were, of course, derived from studying the most prized traditional neighborhoods, but without the self-conscious preciousness of many new urban developments. ${ }^{92}$

The revivals of historic districts represent more than consumer choices; they are a cultural movement. To some extent the phenomenon reflects changes in the global economy. Manufacturing in U.S. cities has nearly disappeared and been replaced by expanding service industries and knowledge institutions, congregating in urban centers and reliant on a highly educated workforce. Cities compete in a global market for businesses that also need to attract highly educated and creative employees. Historic neighborhoods have offered these newcomers attractive older and affordable housing, vacated by prior generations that moved to the suburbs. But it also offered something more. The older buildings, ethnic merchants, and neighborhood stories provided a new, highly educated middle class with a sense of rooted authenticity and belonging. Historian Suleiman Osman has described in penetrating detail the aspirations for a sense of place for "brownstoners," who renovated the neighborhoods of Brooklyn. ${ }^{93}$ They celebrated their "unslumming” neighborhoods as "'historically diverse' —a new romantic urban

\footnotetext{
${ }^{88}$ GLAESER, supra note 8, at 150.

${ }^{89} \mathrm{Id}$.

${ }^{90} I d$. at 149.

${ }^{91} I d$. at 142-43; see also NATHAN GLAZER, From a CAUSE tO A STYLE: MODERNIST ARCHITECTURE's ENCOUNTER WITH THE AMERICAN CITY 63 (2007) (stating that many people have "a taste for the low-rise, the small scale, the unit that gives some privacy, some control, some access to the ground, a small piece of land wholly under one's control”).

${ }^{92}$ Charter of the New Urbanism, CONGRESS FOR THE NEW URBANISM, http://www.cnu.org/charter (last visited Jan. 14, 2012).

${ }^{93}$ SULEIMAN OSMAN, THE INVENTION OF BROWNSTONE BROOKLYN: GENTRIFICATION AND THE SEARCH FOR AUTHENTICITY IN POSTWAR NEW YORK 5-6 (2011) (internal quotation marks omitted).
} 
aesthetic that recast older inner-city districts as sources of anti-bureaucratic authenticity." 94 Osman summarizes:

\begin{abstract}
In a kinetic modern city, brownstones were anchors, their heavy facades giving new white-collar workers a sense of rootedness and permanence in a transient urban environment. . . Echoing a powerful romantic theme, residents were reinhabiting an organic landscape, fleeing university campuses and high-rise apartments to return to a brownstone landscape middle-class forebears once called home. . . . Their stoops, street-level windows, and human-scale design also evoked for new residents the gestalt of an "urban village.” . . Brooklyn Heights represented . . . a "real neighborhood," an authentic local place where genuine human contact and ethnic folk tradition remained uncrushed by alienating modernity and capitalism. ${ }^{95}$
\end{abstract}

Historic districts thus offer a narrative connection with the past. This connection offers cultural meaning and provides some counterpoints to the anomie of modern, rootless capitalism or bureaucracy.

The protection of districts for the meanings they convey is more central to historic preservation than Glaeser's idea of "preserving the most beautiful reminders of our past." ${ }^{96} \mathrm{He}$ mistakes the goals of preservation. Beauty is neither necessary nor sufficient for designation or listing. Indeed, the vernacular buildings that constitute a historic district may convey a more vivid impression of how ordinary people lived in the past than architectural masterpieces designed for the elite. The chief criterion for designation of a historic property is "significance," which connotes its capacity to convey some kind of historic meaning. ${ }^{97}$ This can be seen most readily in the criteria used by the National Park Service in determining whether a property should be listed in the National Register of Historic Places. ${ }^{98}$ Local designation criteria are substantially similar. ${ }^{99}$ The four elements of historical significance relate directly to the values embodied in historic preservation generally. Properties have significance

(a) that are associated with events that have made a significant contribution to the broad patterns of our history;

or

(b) that are associated with the lives of persons significant in our past; or

(c) that embody the distinctive characteristics of a type, period, or method of construction, or that possess high artistic values, or that represent a significant and distinguishable entity whose components may lack individual distinction; or

(d) that have yielded, or may be likely to yield, information important in prehistory or history. ${ }^{100}$

Significance thus embraces places made historically important through association with important events or persons, those with aesthetic or cultural value, and those (including archeological sites) that may provide useful information to the trained eye.

\footnotetext{
${ }^{94}$ Id. at 94, 154 (internal quotation marks omitted).

${ }^{95} \mathrm{Id}$. at $100-03$.

${ }^{96}$ GLAESER, supra note 8, at 260-61.

9736 C.F.R. § 60.4 (2011)

${ }^{98} I d$. (describing the criteria for evaluation as "[t]he quality of significance in American history, architecture, archeology, engineering, and culture").

${ }^{99}$ See, e.g., Designation Procedures and Criteria, D.C. Preservation LeAgue, http://www.dcpreservation.org/districtscrit.html (last visited Jan. 14, 2012) ("Requests for designation are initiated by submitting an application to the [D.C. Historic Preservation Review Board] along with . . . a statement of historic or architectural significance ....”).

100 36 C.F.R. § 60.4
} 
The key for significance is that the structures are able to convey meaning about the past; they exemplify or embody a historical narrative that people in the present value. ${ }^{101}$ Professor Usha Rodrigues recently has attempted to explain the attractions of the non-profit organizations by detailing how membership in or contributions to such entities creates meaning for participants. ${ }^{102}$ Drawing on psychological literature on social identity, she posits that participation in non-profit organizations creates a "warm glow" that for-profit ventures cannot engender. ${ }^{103}$ Something similar may help explain the deeper appeal of historic districts. Developers often seek to provide an image for a new subdivision or apartment building by giving it an evocative name and using architectural details or ornaments that evoke the image. ${ }^{104}$ But such marketing is obviously contrived and inauthentic. Applying Rodrigues' frame for comparing non-profit and for-profit forms, the subdivision's sincerity in expressing a community's meaning is undermined by the conspicuous motive for profit. ${ }^{105}$

By contrast, the buildings and infrastructure now preserved in historic districts were originally created by many hands over some extended period of time. Pre-modern urban residential builders erected a single house or a small row within a public street plan. ${ }^{106}$ The passage of time and generations of occupation obscure the mercenary motives of the original developer. Contemporary residents perceive an authentic expression of past builders and residents in these historic districts that provide a sense of meaning for contemporary living. As Osman argues, this sense of the social meaning of a historic neighborhood, however much enriched by imagination, provides the educated urban brain workers with a nearly pastoral sense of relief or distance from their competitive, bureaucratic workplaces downtown. ${ }^{107}$ French Jesuit theorist Michel de Certeau examined how contemporary urban dwellers seek physical and psychic space outside the hegemonies of prevailing institutions to construct meaning. ${ }^{108}$ Historic districts may serve such a function, providing residents with domestic space dominated neither by large corporate interests nor by government planners.

\section{KOOLHAAS’S CRITIQUE AND SIMILAR COMPLAINTS}

Rem Koolhaas and colleagues at his architecture firm, the Office for Metropolitan Architecture ("OMA"), presented their exhibit, "Cronocaos," in the summer of 2011. ${ }^{109}$ The New Museum in New York City housed the show in a former restaurant supply store, half left in decay and half renovated in a minimalist manner. The show consisted of a series of graphic

\footnotetext{
${ }^{101}$ See id.

${ }^{102}$ Usha Rodrigues, Entity and Identity, 60 EMORY L.J. 1257, 1280 (2011). Phrase comes from article by Brian Galle.

${ }^{103} \mathrm{Id}$.

${ }^{104}$ See Note, Locating the Suburb, 117 HARV. L. REV. 2003, 2013-14 (2004).

${ }^{105}$ Rodrigues, supra note 102, at 1288.

${ }^{106}$ See Robert L. Alexander, Baltimore Row Houses of the Early Nineteenth Century, AM. STUD., Fall 1975, at 65, 68 (describing the popularity of row houses in nineteenth century American cities like Baltimore and Philadelphia).

${ }^{107}$ OSMAN, supra note 93, at 104.

${ }^{108}$ See Michel de Certeau, On the Oppositional Practices of Everyday Life, Soc. TEXT, Fall 1980, at 3, 8

${ }^{109}$ No catalog nor complete reproduction of the exhibit has been published, but both the description of the exhibit and photos can be found online. Cronocaos, N.Y. TimEs, http://www.nytimes.com/

slideshow/2011/05/21/arts/design/koolhaas-ss.html (last visited Jan. 15, 2012) (containing photos of the exhibit); Cronocaos: An

Exhibition by OMA/Rem Koolhaas, NEw MUSEUM, http://www.newmuseum.org/exhibitions/441 (last visited Jan. 15, 2012)

(containing the New Museum's description of the exhibit).
} 
panels, criticizing the aesthetic consequences of historic preservation and showcasing examples of OMA's work as promising alternatives to traditional preservation. Sarah Williams Goldhagen, architecture critic for the New Republic, described the exhibit as "the most high-profile attack on the [historic preservation] movement yet." 110 Nonetheless, the exhibit only communicated a series of polemical ripostes, which were not organized into a logically integrated argument. ${ }^{111}$ Nicolai Ourousoff, architecture critic for the New York Times, articulated the exhibit's thesis:

\begin{abstract}
A skilled provocateur, [Koolhaas] paints a picture of an army of well-meaning but clueless preservationists who, in their zeal to protect the world's architectural legacies, end up debasing them by creating tasteful scenery for docile consumers while airbrushing out the most difficult chapters of history. The result, he argues, is a new form of historical amnesia, one that, perversely, only further alienates us from the past. ${ }^{112}$
\end{abstract}

Koolhaas also argued that too much land has been put under preservation protection; the exhibit presents charts purporting to show that " 12 percent of the earth's surface has already been landmarked." 113

Cronocaos makes some good points. Koolhaas understandably wants to create more leeway for truly creative architecture among historic buildings. Some preservation projects are aesthetically dull or deplorable, or present a deeply sentimental vision of the past yoked to questionable political agendas or commercial exploitation. But other projects are great successes; Koolhaas's design for an addition to the Whitney Museum, incorporating several nineteenth century brownstones, presents a conspicuous example, although it was never built. ${ }^{114}$

The exhibit does not adequately convey the degree to which preservation commissions today approve creative modern additions and juxtapositions to historic properties. Architects have developed satisfying approaches to combining historic fabric and modern additions. ${ }^{115}$ There are several good examples in Washington, D.C., including Norman Foster's glass roof over the courtyard of iconic U.S. Patent Office, which is now part of the Smithsonian American Art Museum. ${ }^{116}$

\footnotetext{
${ }^{110}$ Sarah Williams Goldhagen, Death by Nostalgia, N.Y. TimEs, June 10, 2011, at A21, A21.

${ }^{111}$ Koolhaas also presented an unpublished lecture in New York in May 2011 that elaborated his ideas. Paul Goldberger reported that Koolhaas "complained that contemporary culture has become so obsessive about preserving the past that we risk denying the fundamental premise of architecture, which is to build for the future." Paul Goldberger, Rem Koolhaas at the Festival of Ideas for the New City, New YorkeR (May 10, 2011), http://www.newyorker.com/online/blogs/newsdesk/2011/05/remkoolhaas-at-the-festival-of-ideas-for-the-new-city.html\#ixzz1hlhYmjdU.

${ }^{112}$ Ourousoff, supra note 10 , at C1.

${ }^{113}$ Ourousoff, supra note 10, at C1. The claim about the extent of historic preservation is absurd on its face. The property protected globally by historic preservation is a miniscule percentage of the whole earth. UNESCO, singled out by Koolhaas as an offender, lists only 725 Cultural Sites recognized under the World Heritage Convention. World Heritage List, UNESCO,

http://whc.unesco.org/en/list (last visited Jan. 21, 2012). Moreover, that convention does not directly regulate the alteration of the designated sites, although it is a criterion for listing that the country where the site is located has an adequate legal regime for protecting its outstanding features. UNESCO, Operational Guidelines for the Implementation of the World Heritage Convention, paras. 97-98, U.N. Doc. WHC 11/01 (Nov. 2011), available at http://whc.unesco.org/archive/opguide11-en.pdf.

${ }^{114}$ See Nicolai Ourousoff, Uptown or Down? The Whitney's Identity Crisis, N.Y. TIMES, Nov. 2, 2006, at E1, E6.

${ }^{115}$ See Paul Spencer Byard, The Architecture of AdDitions: Design and Regulation 14 (1998); Steven W. Semes, THE FUTURE OF THE PAST 29 (2009). Architectural approaches to additions and infill development generate substantial and creative controversy. See Catesby Leigh, The Bias Against Tradition, WALL ST. J., Sept. 13, 2011, at D7, D7.

${ }^{116}$ Robert and Arlene Kogod Courtyard, SMITHSONIAN AM. ART MuSEuM,

http://americanart.si.edu/visit/about/architecture/kogod (last visited Jan. 21, 2012).
} 
Koolhaas charges that historic preservation lacks a guiding philosophy of any depth. ${ }^{117}$ But the aimlessness he perceives results from preservation's multiple ambitious goals. Professor Carol Rose grouped the public purposes of preservation into three categories of inspiration, aesthetics, and community building, corresponding to successive phases of the movement. ${ }^{118}$ The first purpose, inspiration, seeks to preserve sites associated with persons and events, forming an important part of the narrative of national or local history. ${ }^{119}$ The second goal is to preserve buildings and other constructions of individual aesthetic merit or that constitute good examples of historic styles or methods. ${ }^{120}$ The third, the most inchoate purpose, and the chief subject of Rose's important article, is to provide legal procedures by which community members identify, articulate, and discuss what physical elements of their neighborhood give it a distinctive identity and how new structures fit in. ${ }^{121}$

None of these purposes are simple nor do they always cohere. Historic preservation can never provide an unproblematic image of the past. Like historical research and writing in relation to an archive, selection and interpretation entwine the concerns of the present and of the interpreter with surviving properties. ${ }^{122}$ For example, antebellum plantation homes survive in significant numbers and have been carefully restored to present the gracious taste of their inhabitants, but slave quarters have almost entirely disappeared, obscuring the realities of their inhabitants' lives. ${ }^{123}$ Moreover, historic preservation functions in real estate or tourist markets where the popular taste and understanding impose limitations on and challenges to critical interpretation. ${ }^{124}$ In another paper, I trace how interpretations of the Gettysburg Battlefield, the site Rose chose as the prime example of preservation for inspiration, ${ }^{125}$ have reflected the concerns of their time, from the Supreme Court's worries about industrial unrest in United States v. Gettysburg Railway Electric Railway Co. ${ }^{126}$ to a contemporary focus on racial justice in Gettysburg's new Visitor Center. ${ }^{127}$ The "significance” criteria at the heart of the designation standard highlight the reality that preservation persists because properties convey meaning that contemporary people find important. Historic preservation then is always at risk of falling into heritage mongering and myth. ${ }^{128}$

Preservationists have long struggled with these issues. Historic preservation law has at least four defenses against a slide to myth. First, original fabric is retained as much as possible in renovations, as emphasized by the Secretary of the Interior's Standards for Treatment of Historic

\footnotetext{
117 See Goldhagen, supra note 110, at A21 (stating the Koolhaas “accused preservationists of aimlessly cherry-picking the past”).

${ }^{118}$ Rose, supra note 37 , at 479-80.

${ }^{119}$ Rose, supra note 37 , at $479-80$.

${ }^{120}$ Rose, supra note 37 , at 480.

${ }^{121}$ Rose, supra note 37, at 488.

122 See Joyce Appleby, Lynn Hunt, \& Margaret Jacob, Telling the Truth About History (1994)(describing the disciplinary norms of historical scholarship)..

${ }^{123}$ See Daniel W. StOWELl, Timucuan ECOlOGiCAl AND Historic Preserve Historic ResourCe StUdy 81 (1996) (stating that well-preserved slave quarters are a rare find); Kathleen Cassedy, Plantations Recall Virginia's Past, CHI. TRIB., Feb. 12, 1989, at 8, 8.

124 David Lowenthal, The Heritage Crusade

${ }^{125}$ Rose, supra note 37, at 482-84.

${ }^{126}$ United States v. Gettysburg Elec. Ry. Co., 160 U.S. 668 (1896).

${ }^{127}$ See generally J. Peter Byrne, Hallowed Ground: The Gettysburg Battlefield in Historic Preservation Law, 22 TUL. ENVTL. L.J. 203 (2009).

${ }^{128}$ See id. at 236-37.
} 
Buildings, the gold standard for preservation. ${ }^{129}$ Second, designation procedures require competent research and documentation about the history of properties to establish their significance. ${ }^{130}$ Third, properties must have "integrity to be eligible for listing," that is, they must retain enough of their original features' character to convey their significance. ${ }^{131}$ Fourth, a massive pluralism pervades contemporary preservation; many kinds of properties have meaning for many different segments of society receive recognition. The National Register of Historic Places lists all sorts of properties having national, state, or local significance. ${ }^{132}$ Enormous efforts have been made to identify and protect places of importance for the history of racial and ethnic minorities and other subordinated people, despite the relative paucity of material remnants of their experiences. ${ }^{133}$ These standards inject a spine of truthfulness into historic preservation, which conforms to our liberal consensus about history itself.

Cronocaos makes one concrete proposal for improved preservation, although the exhibit does not flesh it out. Koolhaas suggests creating preservation edges or sectors in Beijing, where everything from traditional hutongs to recent apartment blocks would be preserved just as they are, but everything else in the city could be demolished and rebuilt without historic restriction. ${ }^{134}$ The exhibit suggests that such wedges "could record, systematically and without aesthetic bias, all the developments that have occurred in an urban system over time." ${ }^{135}$ Such an approach to preservation would be legally infeasible in the U.S. without enormous compensation paid to the owners within the preservation sector, because they would lose all their future development potential. But it does provide a stimulating challenge to the assumptions of preservation practice. The proposal eliminates the selectivity in designation that always has been crucial to preservation law, and it also prohibits the adaptation of historic buildings to contemporary needs. A historian or archeologist might favor Koolhaas's suggestions, because it would leave a layer of material evidence of life at a particular moment in time, something like an archeological deposit. But it fails as historic preservation, because it denies contemporary engagement with the historic

\footnotetext{
${ }^{129}$ Although the Secretary's standards do not express a preference among the treatments of preserving, rehabilitating, restoring, and reconstructing, they do consistently emphasize with each treatment the importance of preserving existing elements and avoiding conjectural additions. For example, a standard for rehabilitation states: "The removal of distinctive materials or alteration of features, spaces and spatial relationships that characterize a property will be avoided.” 36 C.F.R. § 68.3(b)(2) (2011).

${ }^{130}$ U.S. DEP'T OF INTERIOR, NAT’L REGISTER BULLETIN: HOW TO APPLY THE NATIONAL REGISTER CRITERIA FOR EVALUATION 3 (1997).

${ }^{131}$ Applications to the National Register of Historic Places must demonstrate sufficient "integrity to be eligible for listing" or risk rejection. U.S. DEP'T OF INTERIOR, NATIONAL REGISTER OF HISTORIC PLACES REGISTRATION FORM, NPS FORM 10-900: APPLICATION FOR MississipPi Mills PACKING AND ShIPPING RoOMS, at 3 (1990); U.S. Dep’t of Interior, Dingmans Ferry Dutch Reformed Church Carriage Shed, NAT'L PARK SERVICE, http://www.hscl.cr.nps.gov/insidenps/report.asp?STATE=PA\&PARK=DEWA\&STRUCTURE=\&SORT=2\&RECORDNO=3 (last visited Jan. 22, 2012); see also U.S. DEP’T OF INTERIOR, supra note 130, at 44-49 (explaining the various aspects of integrity).

${ }^{132}$ A prime motive for Congress enacting the National Historic Preservation Act was to broaden the National Register to include sites of state and local, as well as national, significance. H.R. REP. No. 89-1916 (1966), reprinted in 1966 U.S.C.C.A.N. 3307, $3309-11$. Sites recently listed on the National Register Weekly List include a 1937 Jewish synagogue in Grand Forks, North Dakota (October 21, 2011), and the Renaissance Revival home of a hops grower in Larimer County, Colorado (August 19, 2011). U.S. Dep’t of Interior, National Register of Historic Places, NAT’L PARK SERVICE, http://www.nps.gov/nr/nrlist.htm (last visited Jan. 22, 2012).

${ }^{133}$ See, e.g., Dolores Hayden, The Power of Place: Urban Landscapes As Public History 39 (1995). The National Park Service supports an annual conference devoted to the Underground Railway, which explores preservation of sites significant to the escape of persons from slavery prior to Emancipation. Annual Conference, NAT’L PARK SERVICE

http://www.nps.gov/subjects/ugrr/community/annual-conference.htm_(last visited Jan. 15, 2012).

${ }^{134}$ Ouroussoff, supra note 10 , at C7.

${ }^{135}$ Beijing Preservation, OMA, http://oma.eu/projects/2003/beijing-preservation (last visited Jan. 15, 2012).
} 
fabric, emphasizing the gulf between the past and the present, which preservation attempts to bridge. ${ }^{136}$ The proposal also obviously permits destruction of most urban structures and the historic value they bear.

Koolhaas and Glaeser both react to a perception that the domain of historic preservation has grown too large. Both argue for deregulation. Glaeser proposes to shrink its application to a few exceptional landmarks; Koolhaas wants to limit preservation regulation so that architects can create new structures with less oversight (and also wants to reorient preservation in some manner). ${ }^{137}$ But as this Article has argued, preservation responds to a widespread cultural need to find meaning in urban space. Sarah Williams Goldhagen, writing in reaction to Cronocaos, also recognizes the broad reach preservation law in modern development process, becoming "de facto, one of the city governments' most powerful instruments for influencing private development." ${ }^{138}$ Her concern is that preservation law functions broadly as design review, that is, a broad inquiry into the aesthetic merits of new architecture, but that volunteer preservation boards have neither the expertise nor the legal standards to integrate new design with broader planning goals. According to Goldhagen, "[d]esign review boards, staffed by professionals trained in aesthetics and urban issues and able to influence planning and preservation decisions, should become an integral part of the urban development process.” ${ }^{139}$

Preservation law surely grew into a vacuum in land use law. Zoning governs use, height, and bulk, but generally does not govern design or integration into public space. Preservation permits neighbors to challenge new construction proposals on the grounds that they are not appropriate or compatible with the existing built environment. Not all disputes address the integrity of historical buildings, but instead may branch into the look and feel of the neighborhood and the nature of the site. Why such issues fall within preservation law is an interesting question deserving of further research. Briefly, many courts in the early twentieth century constitutionally rejected architectural or design review as arbitrary, holding that aesthetics alone was not a constitutionally valid purpose for land use regulation. ${ }^{140}$ Courts more readily accepted historic preservation law, because compatibility with existing buildings provided sufficient guidance for commissions granting permits and for courts reviewing their decisions. ${ }^{141}$ In Europe, planning law has exercised broad control over land development for a long time, and preservation law has not expanded nearly as much to control the character of new development within established neighborhoods. ${ }^{142}$ In the U.S., the constitutional terrain now has

\footnotetext{
${ }^{136}$ In enacting the National Historic Preservation Act, Congress found and declared that "the historical and cultural foundations of the Nation should be preserved as a living part of our community life and development in order to give a sense of orientation to the American people.” 16 U.S.C. § 470(b)(2) (2006).

${ }^{137}$ See Glaeser, supra note 9, at 62; Ouroussoff, supra note 10, at C7.

${ }^{138}$ Goldhagen, supra note 110, at A21.

${ }^{139} \mathrm{Id}$.

${ }^{140}$ See Julian Conrad Juergensmeyer \& Thomas E. Roberts, Land Use Planning and Development Regulation LAW 506-07 (2003).

${ }^{141}$ The Supreme Court early on upheld the use of federal eminent domain for historic preservation because of its capacity to inspire patriotism. United States v. Gettysburg Elec. Ry. Co., 160 U.S. 668, 682 (1896); see also A-S-P Assocs. v. City of Raleigh, 258 S.E.2d 444, 449-50 (N.C. 1979).

${ }^{142}$ One comparison of U.S. with German and Swiss land use law noted that the latter "is a way of restraining the modern economy to protect a traditional way of life. It enforces a prescriptive model of the good city and of the good countryside, and requires the market to operate within that model.” Matthew A. Light, Note, Different Ideas of the City: Origins of Metropolitan Land-Use Regimes in the United States, Germany, and Switzerland, 24 YALE. J. INT’L L. 577, 610 (1999). Arguably, U.S. preservation law has purposes similar to those ascribed to German and Swiss land use law.
} 
shifted sufficiently so that states find aesthetic purposes constitutionally adequate for land use law. ${ }^{143}$

Goldhagen's urging of more professional planning and design review makes sense in some contexts. There is more to sustainable and equitable urban development than compatibility with existing structures, and a greater planning expertise may well advance the public interest in what has become a developer-driven process. The advent of form-based codes may provide the legal basis for regulating the design and orientation of new buildings to enrich the urban context without primary reliance on preservation. Form-based codes govern the exterior form of new buildings, including fenestration, landscaping, façade articulation, and relationship with the street, while relaxing regulation of use. ${ }^{144}$ Thus, land use law has begun to tackle some of the issues directly that have fallen into the domain of preservation law.

But a professionally staffed design review process is not likely to satisfy all the needs served by preservation law. Carol Rose long ago recognized that "the chief function of preservation is to strengthen local community ties and community organization." ${ }^{145}$ She recognized that the physical conditions of a neighborhood help to create a civic identity for a community and that participation in decisions about preservation or new construction enhances that identity. ${ }^{146}$ Preservation of familiar buildings

\begin{abstract}
make[s] a neighborhood or a city "legible" or "imageable" in the viewer's mind. In the legible city, not only can urban dwellers find their way, but the architectural qualities themselves lend drama, interest, an occasion for anecdotes about the past, and thus a framework for identification with the shared experience of the community. $^{147}$
\end{abstract}

Design review by planning professionals would not necessarily embrace a strong presumption against demolition. Goldhagen naively dismisses preservation as "nostalgia," "a grossly reductive dismissal of a powerful cultural impulse. ${ }^{149}$ Moreover, she urges that "city planning offices must be returned to their former, powerful role in urban policy." ${ }_{150}$ History warns that such power could shift decision making to fora where the concerns and voices of community members may have less sway. ${ }^{151}$ In an important sense, preservation law was erected as a shield against planners. In New York, Robert Moses was the archetypal urban planner. Preservationists opposed his grandiose plans to cut highways and erect high rises within historic neighborhoods. ${ }^{152}$ The City's Landmarks Preservation Ordinance grew out of such struggles as

143 JUERGENSMEYer \& RoBerTs, supra note 140, at 507. See Berman v. Parker,

${ }^{144}$ See generally Michael Lewyn, New Urbanist Zoning for Dummies, 58 ALA. L. REv. 257, 268-69 \& n.123 (2006).

${ }^{145}$ Rose, supra note 37, at 479.

${ }^{146}$ Rose, supra note 37, at 534 .

${ }^{147}$ Rose, supra note 37, at 489 .

${ }^{148}$ Goldhagen, supra note 110 , at A21.

149 “Preservation, at its roots, was about an engagement with modernity, not a rejection of it.” Randall Mason, Historic Preservation, Public Memory, and the Making of Modern New York City, in Giving Preservation a History: Histories of Historic Preservation in the United States 131, 157 (Max Page and Randall Mason, eds. 2004).

${ }^{150}$ Goldhagen, supra note 110 , at A21.

${ }^{151}$ See, e.g., Shirley Kressel, Stacked Advisory Groups Pre-Empt Community Voice, S. END NEws, Dec. 8, 2011, at 10, 10.

${ }^{152}$ See, e.g., Paul Goldberger, Robert Moses, Master Builder, Is Dead at 92, N.Y. TIMES, July 31, 1981, at A1, B19 (stating that one critic complained that "Mr. Moses had callously removed residents of neighborhoods undergoing urban renewal" and "destroyed the traditional fabric of urban neighborhoods in favor of a landscape of red-brick towers”). 
much as from destruction of individual buildings like Penn Station. The struggle against planner's megaprojects has helped shape preservation law. ${ }^{153}$

Professional design review seems like an attractive addition to, rather than a replacement for, preservation law. Planning regulations employing form-based codes and site review may lessen the pressure on preservation practice and extend to matters in which cultural heritage or identity play no legitimate role. Moreover, planning doctrine and practice are far more inclusive and modest today than in the urban renewal period, emphasizing pragmatic engagement with the market, dialogue with the community and incremental change. ${ }^{154}$ Historic and environmental regulation have facilitated knowledge about and mandated public comment on plans, and local financial responsibility (rather than federal largesse) has necessitated that elected officials seek public support for projects. ${ }^{155}$ Planning and preservation can learn to coexist. But preservation will not recede, because it responds to the need to live in a place that seems real and enduring, despite or because of the fluidity and complexity of economic and social life.

\section{CONCLUSION}

Glaeser and Koolhaas miss the role of historic preservation to make the modern city hospitable for contemporary life. The urban renewal periods of the 1950's and 1960's put city residents at the mercy of architects and engineers working for the combined power of government and capital. The traditional city had been deemed obsolete and would be replaced by a new city of rationally planned, technologically advanced "machines for living." ${ }^{156}$ But residents rejected this vision, moving into declining neighborhoods, restoring houses, and enacting historic preservation laws. These laws protect traditional structures from demolition, while permitting them to be adapted to current use. They frustrate central control of decision-making and megaprojects and shield smaller scaled, diffused redevelopment. Instead of rationality and efficiency, they elevate community and authenticity.

What Glaeser and Koolhaas do accomplish is that they challenge current preservation law as a final settlement. Glaeser is right that preservation must accommodate the need to provide affordable housing, making the opportunities of city living available to more people. Koolhaas is right that decisions, such as what additions and new construction in historic districts are appropriate and compatible, must not exclude bold creativity that express contemporary visions . The role of historic preservation law in urban development is not itself fixed, but has range to grow toward new maturity. Legal research into its assumptions, methods, and goals should be a growing field.

153 See JUERGENSMEYER \& ROBERTS, supra note 140, at 512-13.

154 See, e.g., Alexander Garvin, THE AMERICAN CITY (2d ed. 2002)

${ }^{155}$ See Alan Altshuler \& David Luberoff, Mega-Projects: The Changing Politics of Urban Public Investment 2-6 (2003); see also 36 C.F.R. pt. 800 (2011) (containing information regarding the Section 106 commenting process under the National Historic Preservation Act); U.S. DeP’T OF LABOR, BuREAU OF LAND MGMT., LAND Use PlanNing HANDBOOK 17 (2005), available at

http://www.blm.gov/pgdata/etc/medialib/blm/ak/aktest/planning/planning_general.Par.65225.File.dat/blm_lup_handbook.pdf (providing a chart demonstrating that public comment is a required step in the regulatory process).

${ }^{156}$ Nicolai Ouroussoff, Machines for Living, N.Y. TIMES, Mar. 16, 2008, at 114 (describing the "nightmare of suburban alienation" as resulting from the "standardized mass production" of development). "Machines for living" borrows from the quote by architect Le Corbusier that "[a] house is a machine for living in.” LE CORBUSIER, TOWARDS A NEW ARCHITECTURE 95 (Frederick Etchells trans. 1986) (1931). 